"Przegląd Prawa Konstytucyjnego"

------ Nr 4 (16)/2013 ------

\title{
Recenzja
}

\section{Systemy polityczne państw bałkańskich, red. Tomasz Bichta, Małgorzata Podolak, Wydawnictwo Uniwersytetu Marii Curie-Skłodowskiej, Lublin 2012, ss. 447}

Problematyka ustrojowa państw bałkańskich od kilku lat cieszy się rosnący zainteresowaniem tak wśród konstytucjonalistów, jak i politologów zajmujących się systemami politycznymi. Stąd obecnie polski Czytelnik może już sięgnąć po dość liczne opracowania tego zagadnienia. Można tu wskazać przede wszystkich prace takich autorów, jak J. Wojnicki ${ }^{1}$, K. Krysieniel $^{2}$ czy E. Bujwid-Kurek ${ }^{3}$. Problematyka ustrojowa państw bałkańskich podejmowana była także w opracowaniach przeznaczonych dla dydaktyki uniwersyteckiej w podręcznikach poświęconych ustrojom państw Europy Środkowej i Wschodniej ${ }^{4}$. Ze zrozumiałych jednak względów ujęcie jej w szerszym zakresowo podręczniku akademickim ograniczało możliwość przedstawienia bardziej pogłębionego obrazu ich ustroju. Tę lukę na rynku księgarskim w sposób udany wypełniają wydane nakładem Wydawnictwa Uniwersytetu Marii Curie-Skłodowskiej Systemy polityczne państw bałkańskich. Są one

1 Zob. np. J. Wojnicki, Przeobrażenia ustrojowe państw postjugosłowiańskich (1990-2003), Pułtusk 2003; idem, Proces instytucjonalizacji przemian ustrojowych w państwach postjugosłowiańskich, Pułtusk 2007.

2 Zob. K. Krysieniel, System polityczny Republiki Chorwacji, Poznań-Chorzów 2007; idem, W cieniu Deyton. Bośnia i Hercegowina między etnokracją i demokracją konsocjonalną, Warszawa 2012.

3 Zob. np. E. Bujwid-Kurek, Państwa pojugosłowiańskie. Szkice politologiczne, Kraków 2008; eadem, Serbia w nowej przestrzeni ustrojowej, Kraków 2012.

4 Zob. np. Systemy polityczne państw Europy Środkowej i Wschodniej. Ustrój, organy wła$d z y$, partie polityczne, red. M. Barański, Katowice 2005; Systemy polityczne państw Europy Środkowej i Wschodniej, red. W. Sokół, M. Żmigrodzki, Lublin 2005. 
owocem prac grupy politologów zajmujących się systemami politycznymi na Wydziale Politologii UMCS.

Autorzy opracowania przyjęli dla potrzeb swojej pracy szerokie pojęcie Bałkanów. Stąd uwzględnienie ustroju Grecji, której ewolucja ustrojowa w czasach nam współczesnych przebiegała w innych warunkach niż pozostałych państw regionu. Uwzględniono także ustrój Turcji. Tu należy zaznaczyć, że trudno uznać Turcję za państwo bałkańskie, tylko niewielki skrawek jej terytorium leży na tym obszarze. Jednak ze względu na kilkaset lat obecności Imperium Osmańskiego na obszarze Bałkanów, co znacząco wpłynęło na losy tego regionu, uwzględnienie - nawet w szerszych zakresie niż ma to miejsce w niniejszym opracowaniu - jej ustroju jest uzasadnione. Dziwi jednak dlaczego Autorzy nie zamieścili w swoim opracowaniu rozdziału poświęconego ustrojowi Republiki Mołdawii. Państwo to bez wątpienia może zostać uznane za państwo bałkańskie. Obszar ten bowiem, tak jak sąsiednia Rumunia, pozostawał aż II połowy XIX w. w zależności od państwa osmańskiego. Dodatkowym argumentem przemawiającym za uwzględnieniem w następnych wydaniach, na które recenzowana pozycja z pewnością zasługuje, także ustroju Mołdawii jest słabe opracowanie tejże problematyki w polskiej literaturze tak konstytucyjnoprawnej, jak i politologicznej ${ }^{5}$.

Sama praca podzielona została na trzynaście rozdziałów, z których dwanaście omawia kolejno w porządku alfabetyczny systemy polityczne poszczególnych państw (Albania, Bośnia i Hercegowina, Bułgaria, Chorwacja, Czarnogóra, Grecja, Kosowo, Macedonia, Rumunia, Serbia, Słowenia i Turcja), zaś trzynasty otwierający książkę poświęcony jest zagadnieniom kształtowania się nowoczesnych narodów w państwach b. Jugosławii (Kiedy etnos stał się demosem: uwarunkowania historyczne głównego podziału socjopolitycznego w państwach postjugosłowiańskich). Rozdział ten stanowi znakomite wprowadzenie pozwalające zrozumieć złożone uwarunkowania, które złożyły się na powstanie obecnie istniejących na obszarze b. Jugosławii państw. Jednak Czytelnik może tu mieć pewien niedosyt, bowiem podobne pogłębione opracowanie nie objęło pozostałych państw regionu.

Należy odnotowywać, że niedawno nakładem Wydawnictwa Sejmowego ukazała się praca R. Rajczak, zob. R. Rajczak, Parlament Mołdowy, Warszawa 2012. 
Z pewnością podobny tekst ich dotyczący spotkałby się z życzliwym przyjęciem Czytelnika.

W odniesieniu do rozdziałów przedstawiających systemy polityczne poszczególnych państw Autorzy zdecydowali się na przyjęcie jednolitej struktury obejmującej przedstawienie kolejno: kształtowania się systemu politycznego, konstytucji i zasad ustrojowych, parlamentu, rządu, prezydenta, władz sądowniczych oraz systemu partyjnego. Od tego schematu Autorzy odchodzili przy omawianiu ustrojów niektórych państw (Bośnia i Hercegowina, Kosowo), było to jednak uzasadnione ich dość oryginalnym ustrojem. Ogólnie można uznać, że taki podział materiału pozwala na zaznajomienie Czytelnika z systemem politycznym danego państwa. Przyjmując taki podział, Autorzy zdecydowali o przedstawieniu zasadniczych elementów systemu politycznego, mniej miejsca poświęcając takim zagadnieniom, jak prawne gwarancje praw człowieka i obywatela czy samorząd terytorialny. Ze względu na to, że niniejsze opracowanie jest pracą zbiorową, widać pewne różnice w sposobie omawiania poszczególnych zagadnień w poszczególnych opracowaniach. Jedni Autorzy kładli większy nacisk na stronę ustrojową, ograniczając tym samym rozważania poświęcone genezie i ewolucji ustrojowej danego państwa czy systemowi partyjnemu. Inni wręcz przeciwnie, właśnie tym elementom poświęcali najwięcej uwagi. Jednocześnie należy podkreślić, że Autorzy w sposób bardzo wyraźny wskazują Czytelnikowi na złożoność współczesnej historii politycznej państw bałkańskich (szczególnie b. Jugosławii), unikając w swoich rozdziałach malowania czarno-białego obrazu niedawnych jeszcze przecież wydarzeń. Wskazują także na zewnętrzne inspiracje niektórych z nich. Ogólnie rzecz ujmując, Autorzy dają Czytelnikowi możliwość zapoznania się z bogatym i dobrze opracowanym materiałem faktograficznym, z uwzględnieniem wskazanego już zróżnicowania w rozłożeniu akcentów. Przy omawianiu niektórych państw słusznie zwraca się uwagę, że proces kształtowania ich ustroju politycznego jeszcze się nie zakończył i może podlegać nawet daleko idącym zmianom. Autorzy poszczególnych rozdziałów nie ograniczają się tylko do przedstawiania tych czy innych zagadnień związanych z systemem politycznych danego państwa na podstawie szerokiej bazy źródłowej, ale także nie unikają przedstawiania własnego stanowiska odnośnie niektórych problemów ustrojowo-politycznych. 
Zasadniczo Autorzy zachowali równowagę między przedstawianiem zagadnień ustrojowych i typowo politologicznych. Pozwala to w pełni zrozumieć, że czasem praktyka ustrojowa może być znacząco odmienna od tego, co wynikałoby z samej tylko lektury tekstu Konstytucji i ustaw. Pewien niedosyt budzi tylko to, że w części poświęconej analizie systemu partyjnego większość Autorów skupiła się na przedstawieniu kształtu systemu partyjnego głównych istniejących partii, ich założeń programowych, wyników wyborów, pomijając instytucjonalne ramy ich działalności, np. kwestię podstaw prawnych działalności, modelu ich finansowania. Sądzę, że uwzględnienie także tego zagadnienia pozwoliłoby w pełni zrozumieć system partyjny poszczególnych państw.

Zrozumienie zagadnień przedstawionych w poszczególnych rozdziałach opracowania ułatwiają nawet nieprzygotowanemu Czytelnikowi tabele i rysunki zamieszczone przez Autorów. Przy czym należy podkreślić, że są one stosowane w sposób właściwy, to jest wówczas, gdy rzeczywiście ułatwiają Czytelnikowi zrozumienie przedstawianego zagadnienia, a nie jedynie dla zapełnienia miejsca. O staranności Autorów przy przygotowaniu opracowania świadczą także tylko nieliczne (kilka) literówki, na jakie udało się trafić piszącemu, czytając recenzowaną pozycję.

Zaletą pracy jest zamieszczona w niej po każdym rozdziale bibliografia obejmująca przede wszystkim prace opublikowane w języku polskim, ale Autorzy powołują także opracowania obcojęzyczne. Przy czym w tym drugim wypadku, co może trochę zaskakiwać, powoływane są przede wszystkim prace anglojęzyczne. Jest to zasadne w odniesieniu do Grecji, Albanii czy Turcji, w tym wypadku znacząca odmienność języka utrudnia korzystanie $z$ tamtejszych prac. Natomiast niedosyt pozostawia to, że Autorzy nie zdecydowali się sięgnąć w szerokim zakresie do prac publikowanych w językach południowosłowiańskich. Jednak ze względu na wykorzystanie przez nich większości liczących się opracowań z polskiej literatury przedmiotu, zarówno książkowych, jak i artykułów, w sposób bardzo dobry wypełnili postawione sobie zadanie. W kwestii opracowań polskich można podnieść kwestię braku nakierowania Czytelnika na istnienie tłumaczenia Konstytucji Kosowa na język polski ${ }^{6}$. Jednocześnie powoływanie opraco-

6 Zob. K. Nowak, Konstytucja Republiki Kosowa, Rzeszów 2010. 
wań polskich jest zdaniem piszącego zasadne z tego względu, że zainteresowany tematem polski Czytelnik w sposób łatwiejszy będzie mógł sięgnąć do pogłębionych studiów w języku polskim niż w językach obcych. Podsumowując, ze względu na bogaty wykaz literatury przedmiotu praca może służyć do dalszych bardziej szczegółowych studiów nad ustrojami poszczególnych przedstawionych w opracowaniu państw. Dodać należy, że bibliografia została przez Autorów podzielona na akty prawne, opracowania i wybrane źródła internetowe. Także sięgnięcie po te ostatnie jest współcześnie coraz bardziej potrzebne.

Recenzowana książka poszerza i systematyzuje wiedzę polskiego Czytelnika na temat współczesnych ustrojów państw bałkańskich. Autorzy przedstawiają $\mathrm{w}$ sposób szczegółowy rozwiązania ustrojowe przyjęte w dwunastu opracowanych przez nich państwach. W tym miejscu ponownie można wyrazić żal, że Autorzy nie zdecydowali się na zaznajomienie Czytelnika z ustrojem Mołdawii. Państwa przedstawione przez Autorów posiadają odmiennie rozwiązania ustrojowe (czasem bardzo oryginalne) mieszczące się jednak w ogólnie pojętych ramach ustroju demokratycznego. Znajdują się także na różnych etapach instytucjonalizacji procesu demokratycznego i rozrachunku z niedawną jeszcze niedemokratyczną przeszłością. Autorzy podkreślają to, wskazując, że w niektórych z wymienionych państw model ustroju nie jest jeszcze ustabilizowany i może podlegać czasem daleko idącym zmianom. Wypada wyrazić radość, że problematyka ustrojów państw bałkańskich, z którymi łączy Polskę doświadczenie zarówno niedawnej przecież niedemokratycznej przeszłości, jak i w ogólnym ujęciu podobne problemy związane z transformacją ustrojową, jest coraz częściej obiektem dociekań naukowych ze strony przedstawicieli doktryny. Warto także zwrócić uwagę na bliskość geograficzną i z częścią z przedstawionych państw także kulturową.

Opracowanie zostało napisanie językiem jasnym i komunikatywnym. Umożliwia to Czytelnikowi, który przecież nie musi być znawcą zagadnień ustrojowych czy politycznych, łatwe zapoznanie się z tematyką książki. Z tego względu Systemy polityczne państw bałkańskich mogą służyć pomocą nie tylko w dydaktyce uniwersyteckiej w ramach przedstawiania problematyki ustrojowo-politycznej państw bałkańskich, ale można ją polecić wszystkim Czytelnikom zainteresowanym współczesnymi Bałkanami. Książka ta 
powinna się także znaleźć w podręcznej bibliotece konstytucjonalistów oraz politologów zajmujących się systemami politycznymi, ponieważ zawarty w niej zasób informacji umożliwia dokonywanie pogłębionych studiów porównawczych. Po Systemy polityczne państw bałkańskich powinni także sięgnąć dziennikarze piszący o państwach bałkańskich.

Andrzej Pogłódek Uniwersytet Kardynała Stefana Wyszyńskiego 